\title{
Perancangan Sistem Informasi Jasa Wedding Organizer pada CV. Boganesia Jaya Berbasis Web
}

\author{
Difia Agustin*1, Alexius Ulan Bani², Fauziyah ${ }^{3}$ \\ 123Program Studi Sistem Informasi, Fakultas Ilmu Komputer, \\ Universitas Bung Karno, Indonesia \\ Jl. Kimia No. 20, Jakarta Pusat \\ Email: *1difiaagustin18@gmail.com, ${ }^{2}$ alexiusulanbani@ubk.ac.id, ${ }^{3}$ fauziyah@ubk.ac.id
}

\begin{abstract}
$C V$. Boganesia Jaya is a business company in the field of wedding organizer services. Currently it can be seen that in ordering a wedding package that is on the CV. Boganesia Jaya has not used the system or is still using manual methods, namely customers must come directly to the place to order a wedding package and the order will be recorded in the ledger. In this case some suggestions can be given to the company for further development through an information system designed using a PHP web-based application and the MySQL programming language to solve this problem in $C V$. Boganesia Jaya which is more effective and accurate.
\end{abstract}

Keywords: information systems, wedding organizer, PHP, MYSQL.

\section{PENDAHULUAN}

Perkembangan ilmu pengetahuan dan teknologi di era globalisai yang telah berevolusi pada dunia kerja mengharuskan masyarakat ikut serta dalam perkembangan tersebut (Mukhadis, 2013). Hal ini ditandai dengan adanya dengan teknologi modern yang dapat memudahkan segalanya, sebagai contoh adalah dengan bisnis perdagangan barang atau jasa melalui website (Hamzah \& Hadjib, 2013). Saat ini website supaya lebih dinamis sudah dihubungkan dengan data base antara lain MySql (Taryana \& Taryanarx, 2006) Oleh karena itu, saat ini banyak bisnis perdagangan barang atau jasa yang menjual atau menyewakan barang dagangan mereka melalui internet, salah satu contohnya-yaitu bisnis perdagangan jasa wedding organizer.

Wedding Organizer yang dimiliki CV Boganesia Jaya merupakan salah satu bisnis perdagangan dalam bidang jasa yang membantu dan mempermudah calon pengantin dan keluarga dalam merencanakan acara pernikahan sesuai dengan harga dan jadwal yang telah ditetapkan. Sedangkan permasalahan yang ada pada wedding organizer CV. Boganesia Jaya saat ini adalah pemesanan paket pernikahan dilakukan secara manual oleh calon pengantin dengan datang langsung ke tempat $\mathrm{CV}$ Boganesia Jaya ini berada dan pencatatan pemesanan paket pernikahan masih menggunakan buku besar.

Penulisan ini bertujuan untuk menganalisa dan membangun sistem informasi jasa wedding organizer pada CV Boganesia Jaya berbasis web menggunakan PHP dan MySql, membuat pemodelan dengan menggunakan Unifed Modelling Language (UML) pada sistem informasi yang berjalan pada CV Boganesia Jaya, dan melakukan pengujian sistem informasi pada CV Boganesia Jaya dengan metode blackbox.

Hal yang terkait dengan perancangan sistem informasi jasa weddingorganiser antara lain adalah:

\section{Perancangan}

Perancangan yaitu suatu proses mendefinisikan sesuatu yang dikerjakan serta melibatkan deskripsi didalamnya tentang arsitektur serta komponen yang detail dan keterbatasan-keterbatasan yang dialami selama proses pengerjaannya menggunakan teknik yang bervariasi (Soetam, 2011)

\section{Sistem Informasi}

Sistem informasi merupakan perkumpulan dari tiga perangkat penting yaitu perangkat keras (hardware), perangkat lunak (software) dan juga perangkat manusia (brainware) yang mempunyai tugas mengelolah dan juga menggunakan kedua perangkat lainnya 
yaitu perangkat keras dan perangkat lunak (Kristanto, 2018)

Jasa

Jasa ialah setiap manfaat, setiap kegiatan atau juga setiap performance yang telah ditawarkan oleh satu pihak kepada pihak yang lainnya lalu memiliki sifat intangible serta tidak akan terjadi perpindahan kepemilikan apapun dalam bentuk produksinya terikat maupun tidak terikat dengan produk fisik (Kolter \& Kevin, 2012).

\section{Wedding Organizer}

Wedding Organizer ialah bentuk jasa khusus yang membantu para calon pengantin dan juga keluarganya dalam merencanakan dan mengawasi rangkaian pelaksanaan acara pernikahan sesuai dengan jadwal dan waktu yang telah ditetapkan (widhardin, 2010).

MySQL

MySQL adalah Sebuah perangkat lunak sistem manajemen basis data SQL. MySQL ialah multi-user yang bebas dari biaya di bawah lisensi GNU General Public License (GPL) dan merupakan DBMS yang multithread (Anhar, 2010).

\section{Blackbox Testing}

Pengujian yang bertipe memperlakukan sebuah perangkat lunak yang tidak diketahui kinerja dan spesifikasi fungsional didalamnya (internal) (Soetam, 2011; Mustaqbal et al., 2015).

\section{METODE PENELITIAN}

Metode yang digunakan dalam penelitian ini secara komperhensip menggabungkan beberapa metode dimulai dengan studi pustaka, kemudian dilanjutkan dengan obserbasi, perancangan sistem, pemrograman sistem, dan pengujian sistem.

Studi pustaka dilakukan dengan mengambil beberapa referensi yang berkaitan dengan judul penelitian dengan melakukan tinjauan pustaka guna menunjang pembuatan penelitian yang lebih baik. Setelah studi pustaka dilanjutkan dengan observasi pada CV. Boganesia Jaya, untuk mengetahui dengan pasti kegiatan-kegiatan serta proses-proses yang berjalan pada Wedding Organizer CV. Boganesia Jaya.

Setelah melakukan observasi dilanjutkan dengan perencanaan system, pada tahap ini perancangan sistem yang dilakukan berupa perancangan Unifed Modelling Language
(UML). Setelah rancangan system terbentuk, tahapan selanjutnya adalah menuliskan kode program (coding) yang merupakan penerjemah desain dalam Bahasa program dengan menggunakan PHP, CSS, dan HTML. Untuk pembuatan database aplikasi yang dibangun menggunakan MySQL.

Tahap terakhir yaitu pengujian sitem yang bertujuan untuk memastikan program telah selesai dan menghindari terjadinya error atau kesalahan pada aplikasi saat dijalankan. Pengujian dilakukan dengan menggunakan metode Blackbox Testing.

\section{HASIL DAN PEMBAHASAN Perancangan Sistem}

1. Analisa Kebutuhan Sistem

Setelah dilakukan analisis dieproleh kebutuhan dari masing-masing pengguna antara lain:

a. Halaman Admin

Admin dapat melihat daftar pembayaran, dapat mengelolah data paket pernikahan, data customer, dan data pemesanan.

b. Halaman Finance

Finance dapat melihat daftar pemesanan dan dapat mengelolah data pembayaran.

c. Halaman Owner

Owner dapat melihat daftar pemesanan, daftar pembayaran dan dapat melihat laporan transaksi.

d. Halaman Customer

Customer harus registrasi terlebih dahulu untuk memesan paket pernikahan yang diinginkan, dapat mengecek harga dan detail paket pernikahan, dapat melakukan konfirmasi pembayaran, dapat melihat status pemesanan dan pembayaran.

2. Use Case Diagram Bisnis Usulan

Use case diagram merupakan gambaran aktivitas yang berjalan dilihat dari kebutuhan aktor. Pada tahapan ini menggambarkan hubungan antara aktor dan sistem yang diusulkan, dapat dilihat pada Gambar 1. 


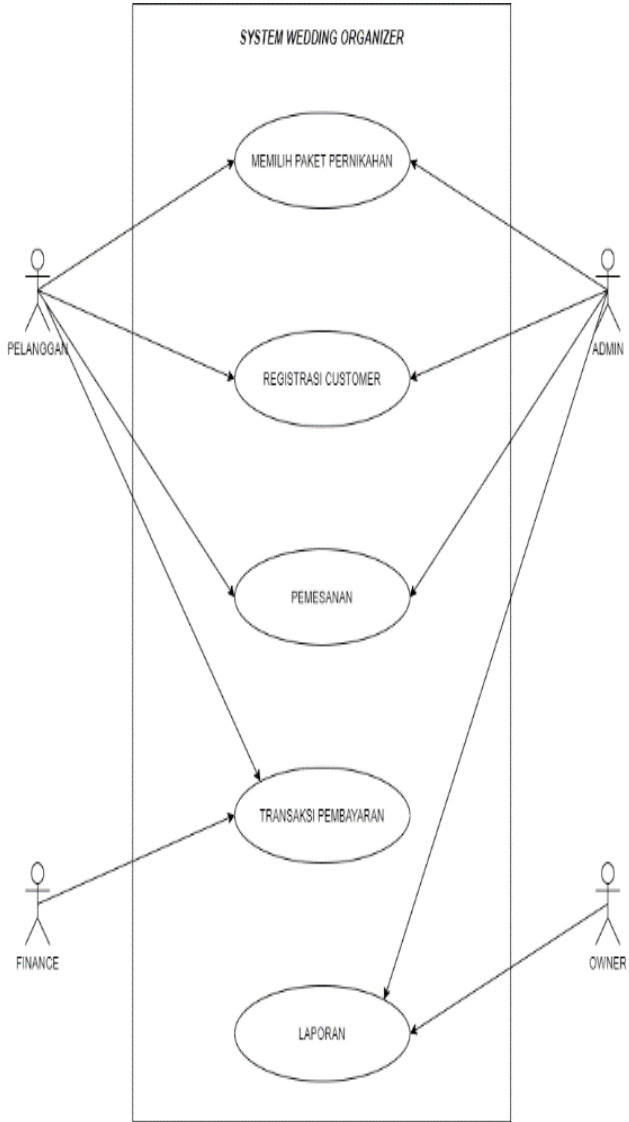

Gambar 1 Use Case Diagram Bisnis Usulan

3. Sistem Use Case Aplikasi Usulan

Gambaran sistem usulan yang berjalan dapat dilihat pada Gambar 2.

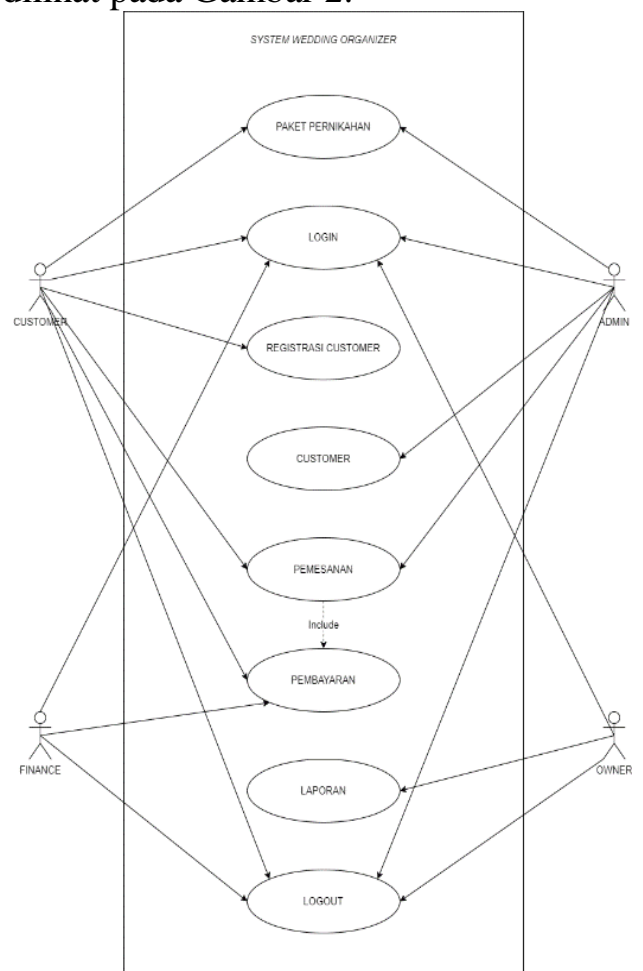

Gambar 2 Use Case Diagram Aplikasi Usulan
4. Perancangan Antar Muka (User Interface) Perancangan antar muka aplikasi sistem informasi jasa wedding organizer yang telah dianalisa untuk itu dalam pembuatan tampilan antar muka sangat membutuhkan tahap perancangan agar dapat menghasilkan informasi yang dibutuhkan secara cepat, tepat dan akurat. Gambar 3 di bawah ini merupakan struktur menu sistem informasi jasa wedding organizer pada CV. Boganesia Jaya.

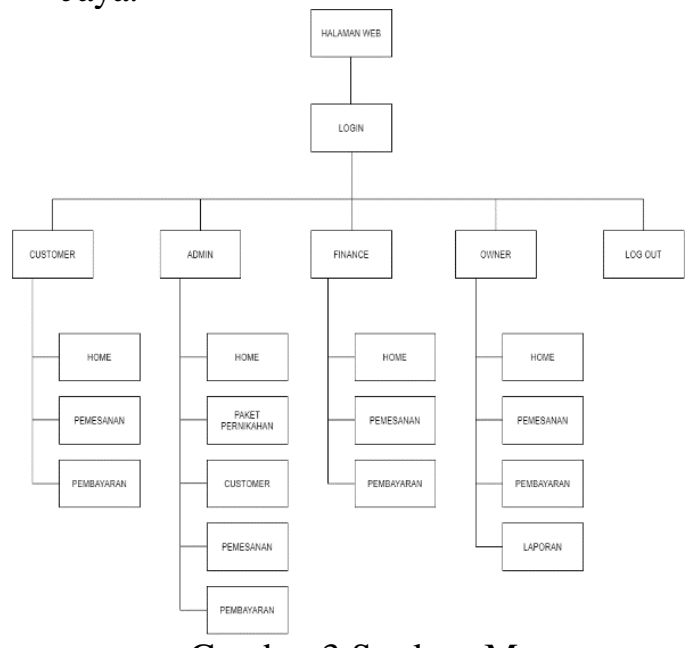

Gambar 3 Struktur Menu

Implementasi Antar Muka (User Interface)

Tahap implementasi dilakukan setelah tahap analisa dan perancangan telah selesai dikerjakan, yang digambarkan dengan tampilan user interface program dari sistem yang dirancang atau diusulkan di bawah ini.

1. Tampilan halaman utama internal dan eksternal dapat dilihat pada Gambar 4.

cv. Boganesia Jaya loge

Paket Pernikahan
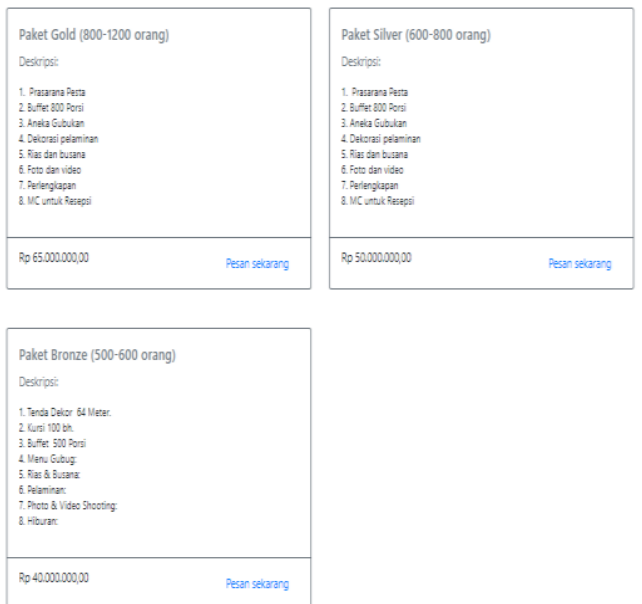

Gambar 4 Halaman Utama Internal dan Eksternal 
2. Tampilan login internal dan eksternal dapat dilihat pada Gambar 5.

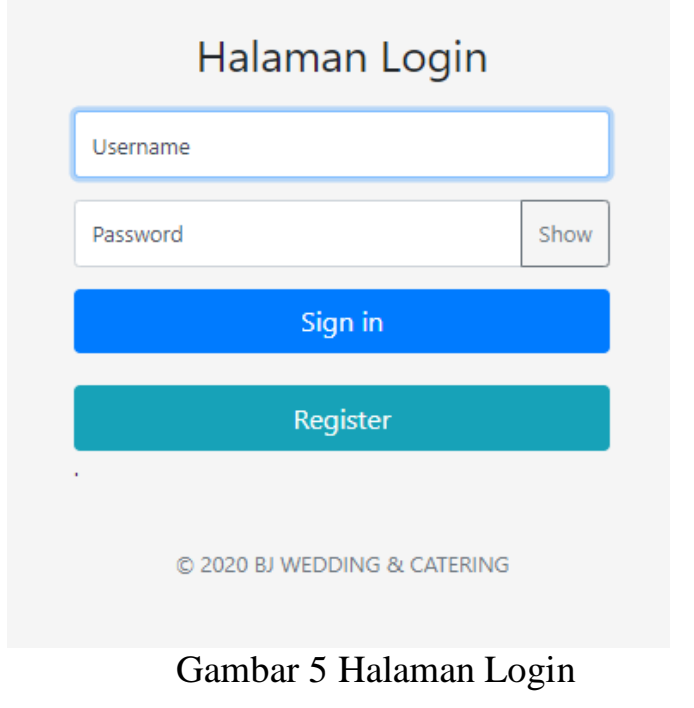

3. Tampilan halaman registrasi cutomer dapat dilihat pada Gambar 6.

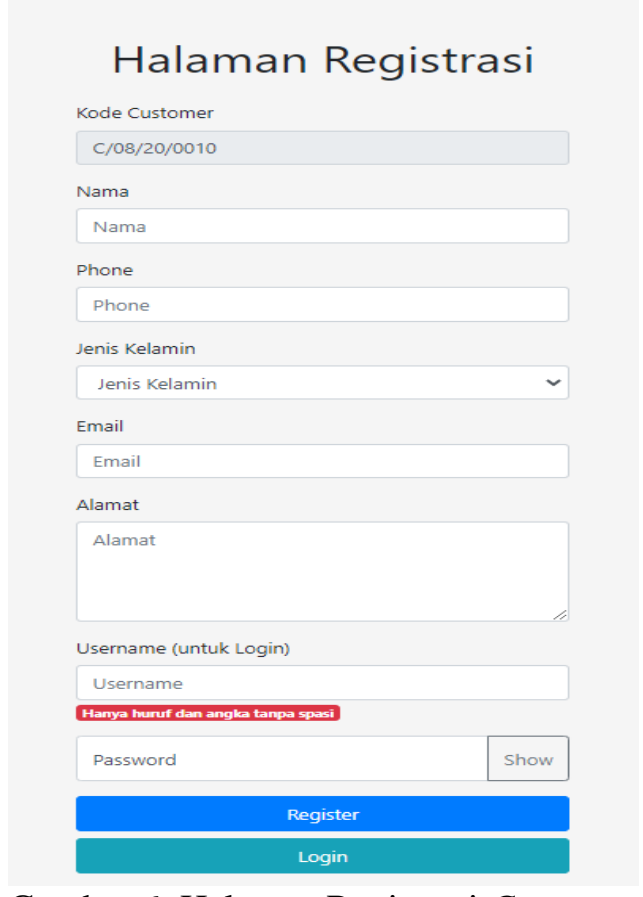

Gambar 6. Halaman Registrasi Customer
4. Tampilan halaman utama customer dapat dilihat pada Gambar 7.

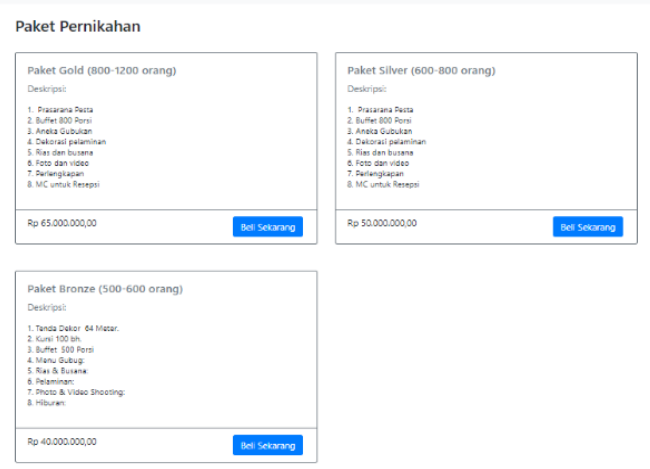

Gambar 7 Halaman Utama Customer

5. Tampilan daftar pemesanan untuk customer dapat dilihat pada Gambar 8.

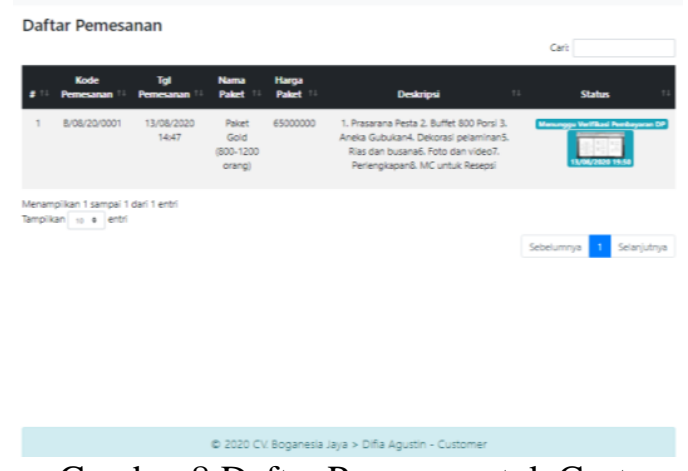

Gambar 8 Daftar Pesanan untuk Customer

6. Tampilan daftar pembayaran untuk customer dapat dilihat pada gambar 9 .

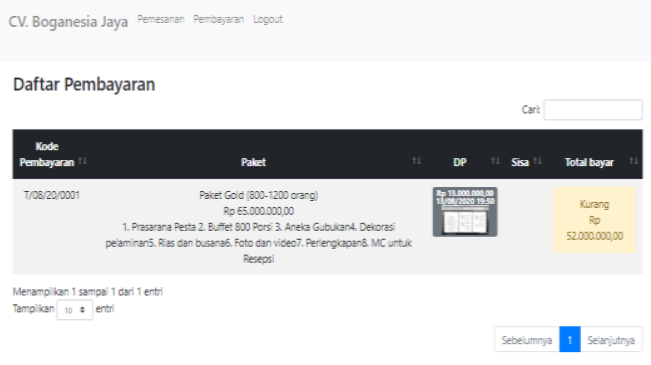

Gambar 9 Daftar Pembayaran untuk Customer 
7. Tampilan pembayaran untuk customer dapat dilihat pada Gambar 10.

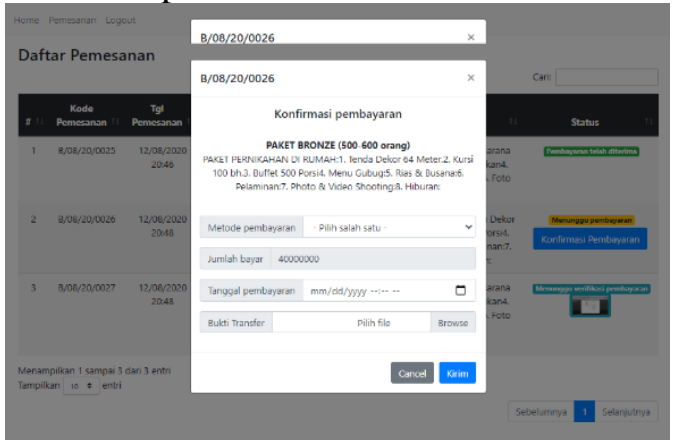

Gambar 10 Pembayaran untuk Customer

8. Tampilan pemesanan untuk customer dapat dilihat pada Gambar 11.

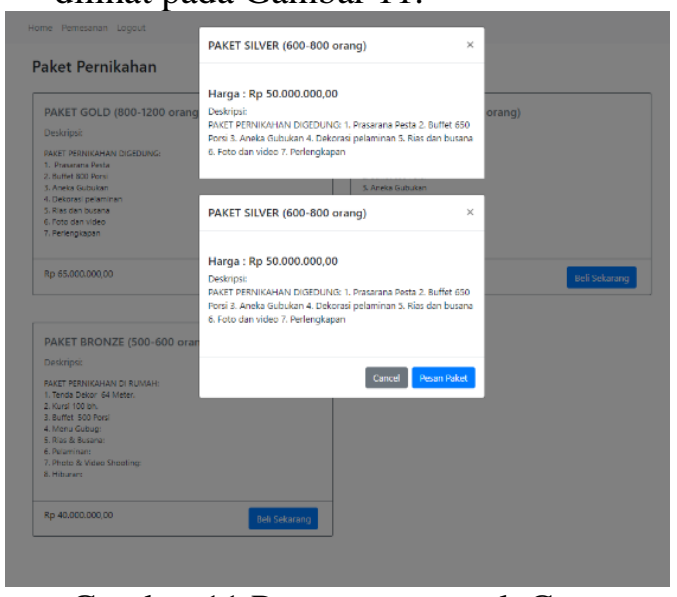

Gambar 11 Pemesanan untuk Customer

9. Tampilan halaman utama admin dapat dilihat pada Gambar 12

Selamat Datang

Hosto dimin

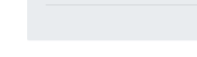

10.Tampilan paket pernikahan untuk admin dapat dilihat pada Gambar 13.

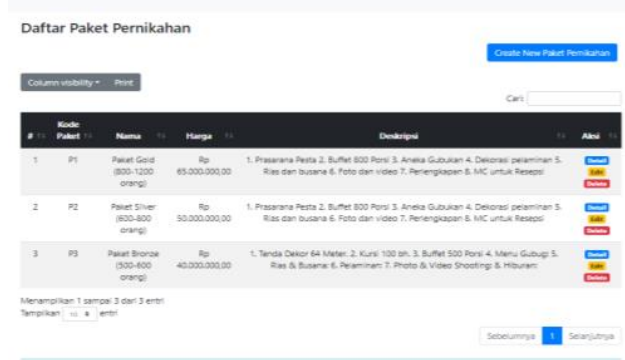

Gambar 13 Paket Pernikahan untuk Admin

11.Tampilan form paket pernikahan dapat dilihat pada Gambar 14.

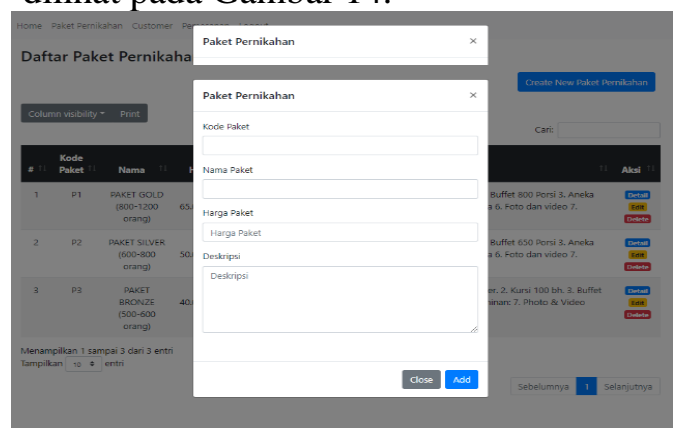

Gambar 14 Form Paket Pernikahan

12. Tampilan customer untuk admin dapat dilihat pada Gambar 15.

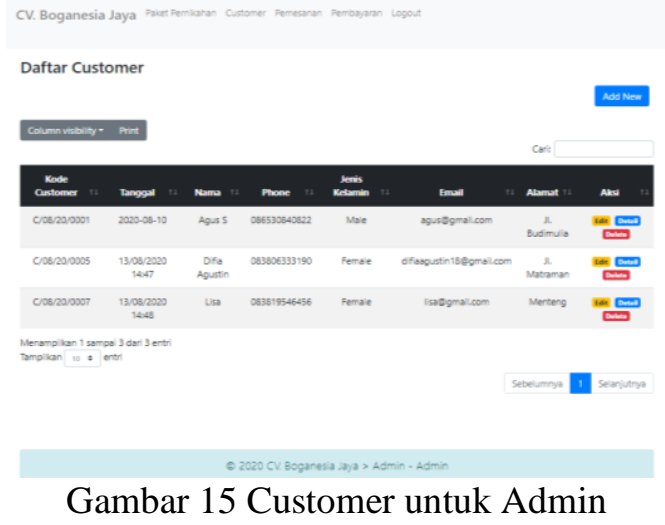

Gambar 12 Halaman Utama Admin 
13. Tampilan form customer dapat dilihat pada Gambar 16.

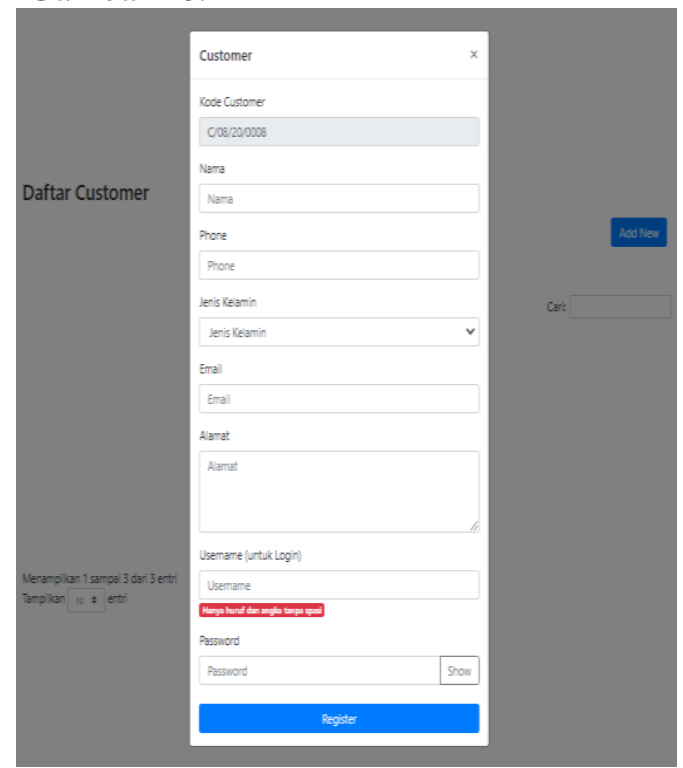

Gambar 16 Form Customer

14. Tampilan pemesanan untuk admin dapat dilihat pada Gambar 17.

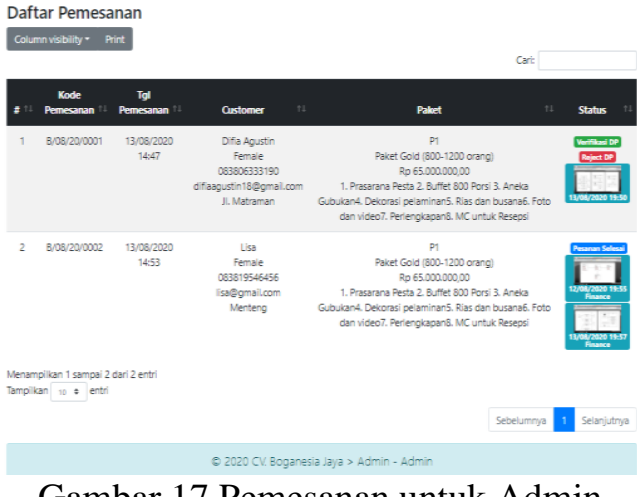

15. Tampilan pembayaran untuk admin dapat dilihat pada Gambar 18.
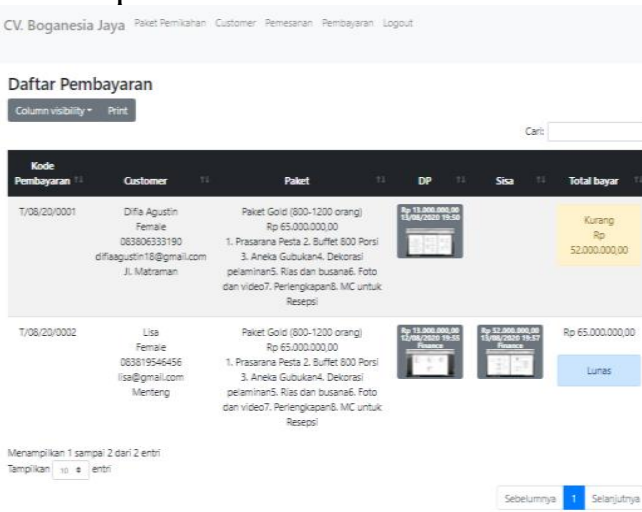

16. Tampilan halaman utama Finance dapat dilihat pada Gambar 19.

Selamat Datang

salo frences

Gambar 19 Halaman Utama Finance

17. Tampilan daftar pemesanan untuk Finance dapat dilihat pada Gambar 20.

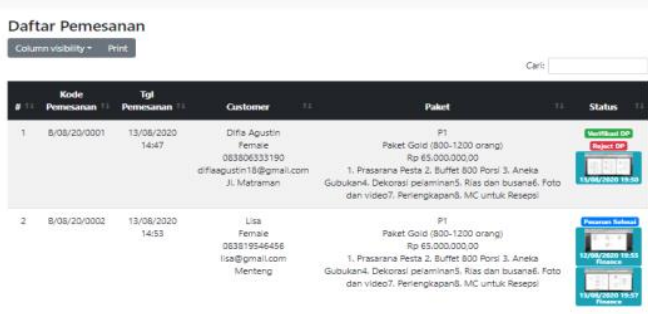

$\cos 2$

Gambar 20 Daftar Pemesanan untuk Finance

18. Tampilan daftar pembayaran untuk Finance dapat dilihat pada Gambar 21.

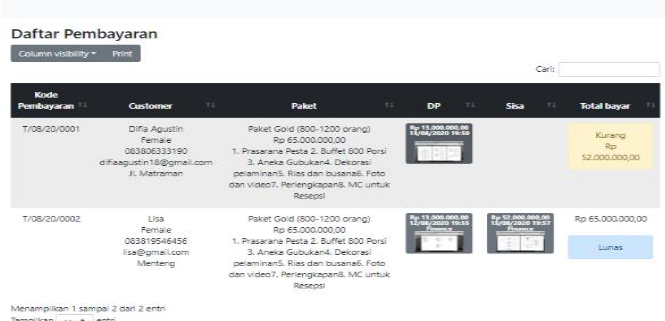

Gambar 21 Daftar Pembayaran untuk Finance

19. Tampilan halaman utama Owner dapat dilihat pada Gambar 22.

Selamat Datang

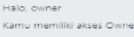

Gambar 22 Halaman Utama Owner

Gambar 18 Pembayaran untuk Admin 
20. Tampilan pemesanan untuk Owner dapat dilihat pada Gambar 23.

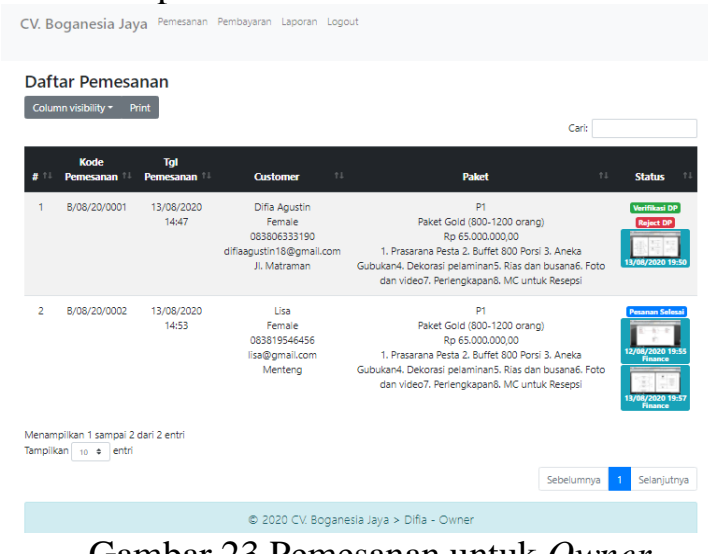

Gambar 23 Pemesanan untuk Owner

21. Tampilan pembayaran untuk Owner dapat dilihat pada Gambar 24.
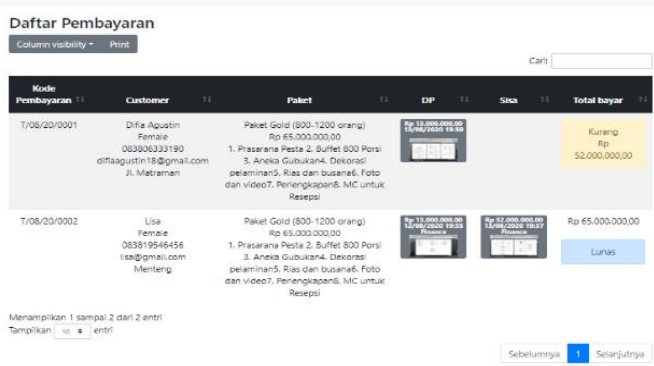

Gambar 2. Pembayaran untuk Owner
22. Tampilan laporan dapat dilihat pada Gambar 25.

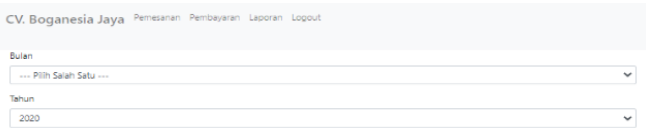

\section{Pengujian Sistem}

Pengujian ini dilakukan untuk melihat suatu program apakah telah memenuhi atau belum. Untuk pengujian blackbox testing pada aplikasi ini, dapat dilihat pada Tabel 1 .

Tabel 1. Tabel Pengujian Blackbox

\begin{tabular}{|c|l|l|c|}
\hline No. & \multicolumn{1}{|c|}{ Skenario Pengajuan } & \multicolumn{1}{|c|}{ Expected Result } & Kesimpulan \\
\hline 1 & $\begin{array}{l}\text { Mengkosongkan semua isian } \\
\text { dari data login, lalu klik } \\
\text { tombol "sign in". }\end{array}$ & $\begin{array}{l}\text { Sistem akan menolak dan } \\
\text { menampilkan pesan "Please fill } \\
\text { out this field". }\end{array}$ & Valid \\
\hline 2 & $\begin{array}{l}\text { Memasukkan username dan } \\
\text { password yang salah. Lalu } \\
\text { mengklik tombol "sign in". }\end{array}$ & $\begin{array}{l}\text { Sistem akan menolak dan } \\
\text { menampilkan pesan "Maaf, } \\
\text { Username atau Password } \\
\text { salah". }\end{array}$ & Valid \\
\hline 3 & $\begin{array}{l}\text { Memasukkan data login yang } \\
\text { benar pada akses semua } \\
\text { aktor. Lalu mengklik tombol } \\
\text { "sign in". }\end{array}$ & $\begin{array}{l}\text { Sistem menerima akses dan } \\
\text { kemudian menampilkan } \\
\text { halaman utama masing-masing } \\
\text { aktor. }\end{array}$ & Valid \\
\hline 4 & $\begin{array}{l}\text { Mengkosongkan semua isian } \\
\text { pada halaman registrasi. Lalu } \\
\text { mengklik tombol "register". }\end{array}$ & $\begin{array}{l}\text { Sistem akan menolak, data } \\
\text { tidak akan disimpan dan } \\
\text { menampilkan pesan "Please fill } \\
\text { out this field". }\end{array}$ & Valid \\
\hline 5 & $\begin{array}{l}\text { Mengisi semua data yang } \\
\text { diminta pada halaman } \\
\text { registrasi, lalu klik tombol } \\
\text { "register". }\end{array}$ & $\begin{array}{l}\text { Data akan disimpan dan sistem } \\
\text { akan menampilkan halaman } \\
\text { utama untuk customer. }\end{array}$ & Valid \\
\hline
\end{tabular}




\begin{tabular}{|c|c|c|c|}
\hline 6 & $\begin{array}{l}\text { Customer mengklik tombol } \\
\text { "Beli Sekarang" pada salah } \\
\text { satu paket pernikahan. } \\
\text { Kemudian mengklik tombol } \\
\text { "Pesan Paket". }\end{array}$ & $\begin{array}{l}\text { Sistem akan menyimpan } \\
\text { pesanan tersebut dan akan } \\
\text { menampilkan daftar pesanan } \\
\text { customer. }\end{array}$ & Valid \\
\hline 7 & $\begin{array}{l}\text { Customer mengklik menu } \\
\text { pemesanan. }\end{array}$ & $\begin{array}{l}\text { Sistem akan menampilkan } \\
\text { daftar pesanan pelanggan. }\end{array}$ & Valid \\
\hline 8 & $\begin{array}{l}\text { Customer mengklik menu } \\
\text { pembayaran. }\end{array}$ & $\begin{array}{l}\text { Sistem akan menampilkan } \\
\text { daftar pembayaran. }\end{array}$ & Valid \\
\hline 9 & $\begin{array}{l}\text { Customer mengklik tombol } \\
\text { "Konfirmasi pembayaran } \\
\text { DP". }\end{array}$ & $\begin{array}{l}\text { Sistem akan menampilkan form } \\
\text { konfirmasi pembayaran DP. }\end{array}$ & Valid \\
\hline 10 & $\begin{array}{l}\text { Customer mengkosong kan } \\
\text { data atau hanya mengisi } \\
\text { sebagian data pada form } \\
\text { konfirmasi pembayaran DP. } \\
\text { Lalu mengklik tombol } \\
\text { "kirim". }\end{array}$ & $\begin{array}{l}\text { Sistem akan menolak, data } \\
\text { tidak akan disimpan dan } \\
\text { menampilkan pesan "Please fill } \\
\text { out this field". }\end{array}$ & Valid \\
\hline 11 & $\begin{array}{l}\text { Customer mengisi semua data } \\
\text { yang dibutuhkan dengan } \\
\text { benar pada form konfirmasi } \\
\text { pembayaran DP. Lalu } \\
\text { mengklik tombol "kirim". }\end{array}$ & $\begin{array}{lrr}\text { Data akan disimpan } & \text { kedalam } \\
\text { sistem dan } & \text { sistem } & \text { akan } \\
\text { menampilkan } & & \text { daftar } \\
\text { pemesanan. } & & \end{array}$ & Valid \\
\hline 12 & $\begin{array}{l}\text { Customer mengklik tombol } \\
\text { "Konfirmasi } \\
\text { pembayaran". }\end{array}$ & $\begin{array}{l}\text { Sistem akan menampilkan form } \\
\text { konfirmasi pembayaran sisa } \\
\text { tagihan. }\end{array}$ & Valid \\
\hline 13 & $\begin{array}{l}\text { Customer mengkosong kan } \\
\text { data atau hanya mengisi } \\
\text { sebagian data pada form } \\
\text { konfirmasi pembayaran sisa } \\
\text { tagihan. Lalu mengklik } \\
\text { tombol "kirim". }\end{array}$ & $\begin{array}{l}\text { Sistem akan menolak, data } \\
\text { tidak akan disimpan dan } \\
\text { menampilkan pesan "Please fill } \\
\text { out this field". }\end{array}$ & Valid \\
\hline 14 & $\begin{array}{l}\text { Customer mengisi semua data } \\
\text { yang dibutuhkan dengan } \\
\text { benar pada form konfirmasi } \\
\text { pembayaran sisa tagihan. } \\
\text { Lalu mengklik tombol } \\
\text { "kirim". }\end{array}$ & 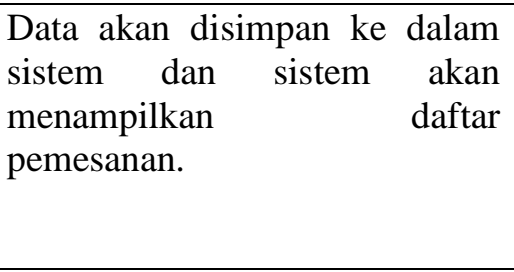 & Valid \\
\hline 15 & $\begin{array}{l}\text { Admin mengklik menu paket } \\
\text { pernikahan. }\end{array}$ & $\begin{array}{l}\text { Sistem akan menampilkan } \\
\text { daftar paket pernikahan. }\end{array}$ & Valid \\
\hline 16 & $\begin{array}{lcr}\text { Admin mengklik } & \text { tombol } \\
\text { "creat } & \text { new } & \text { paket } \\
\text { pernikahan". } & \\
\end{array}$ & $\begin{array}{l}\text { Sistem akan menampilkan form } \\
\text { paket pernikahan. }\end{array}$ & Valid \\
\hline 17 & $\begin{array}{l}\text { Admin mengkosongkan data } \\
\text { atau mengisi sebagian data } \\
\text { pada form paket pernikahan. } \\
\text { Lalu mengklik tombol "add". }\end{array}$ & $\begin{array}{l}\text { Sistem akan menolak, data } \\
\text { tidak akan disimpan dan } \\
\text { menampilkan pesan "Please fill } \\
\text { out this field". }\end{array}$ & Valid \\
\hline 18 & $\begin{array}{l}\text { Admin mengisi semua data } \\
\text { yang dibutuhkan dengan } \\
\text { benar pada form paket } \\
\text { pernikahan. Lalu mengklik } \\
\text { tombol "add". }\end{array}$ & $\begin{array}{llr}\text { Data akan disimpan ke } & \text { dalam } \\
\text { sistem dan } & \text { sistem } & \text { akan } \\
\text { menampilkan } & \text { daftar } & \text { paket } \\
\text { pernikahan. } & & \end{array}$ & Valid \\
\hline
\end{tabular}




\begin{tabular}{|c|c|c|c|}
\hline 19 & $\begin{array}{l}\text { Admin mengklik menu } \\
\text { customer. }\end{array}$ & $\begin{array}{l}\text { Sistem akan menampilkan } \\
\text { daftar customer. }\end{array}$ & Valid \\
\hline 20 & $\begin{array}{l}\text { Admin mengklik tombol "add } \\
\text { new" yang ada di dalam menu } \\
\text { customer. }\end{array}$ & $\begin{array}{l}\text { Sistem akan menampilkan form } \\
\text { customer. }\end{array}$ & Valid \\
\hline 21 & $\begin{array}{l}\text { Admin mengkosongkan data } \\
\text { atau mengisi sebagian data } \\
\text { pada form customer. Lalu } \\
\text { mengklik tombol "register". }\end{array}$ & $\begin{array}{l}\text { Sistem akan menolak, data } \\
\text { tidak akan disimpan dan } \\
\text { menampilkan pesan "Please fill } \\
\text { out this field". }\end{array}$ & Valid \\
\hline 22 & $\begin{array}{l}\text { Admin mengisi semua data } \\
\text { yang dibutuhkan dengan } \\
\text { benar pada form customer. } \\
\text { Lalu mengklik tombol } \\
\text { "register". }\end{array}$ & $\begin{array}{l}\text { Data akan disimpan ke dalam } \\
\text { sistem. }\end{array}$ & Valid \\
\hline 23 & $\begin{array}{l}\text { Admin mengklik menu } \\
\text { pemesanan. }\end{array}$ & $\begin{array}{l}\text { Sistem akan menampilkan } \\
\text { daftar pemesanan. }\end{array}$ & Valid \\
\hline 24 & $\begin{array}{l}\text { Admin mengklik tombol } \\
\text { "terima" pada status yang ada } \\
\text { pada menu pemesanan. }\end{array}$ & $\begin{array}{l}\text { Sistem akan mengubah status } \\
\text { menjadi "pesanan diterima". }\end{array}$ & Valid \\
\hline 25 & $\begin{array}{l}\text { Admin mengklik menu } \\
\text { pembayaran. }\end{array}$ & $\begin{array}{l}\text { Sistem akan menampilkan } \\
\text { daftar pembayaran. }\end{array}$ & Valid \\
\hline 26 & $\begin{array}{l}\text { Finance mengklik menu } \\
\text { pemesanan. }\end{array}$ & $\begin{array}{l}\text { Sistem akan menampilkan } \\
\text { daftar pemesanan. }\end{array}$ & Valid \\
\hline 27 & $\begin{array}{l}\text { Finance mengklik tombol } \\
\text { "verifikasi DP" pada status } \\
\text { yang ada pada menu } \\
\text { pemesanan. }\end{array}$ & $\begin{array}{l}\text { Sistem akan mengubah status } \\
\text { menjadi "DP diterima". }\end{array}$ & Valid \\
\hline 28 & $\begin{array}{l}\text { Finance mengklik tombol } \\
\text { "reject DP" pada status yang } \\
\text { ada pada menu pemesanan. }\end{array}$ & $\begin{array}{l}\text { Sistem akan mengubah status } \\
\text { menjadi "DP ditolak". }\end{array}$ & Valid \\
\hline 29 & $\begin{array}{l}\text { Finance mengklik menu } \\
\text { pembayaran. }\end{array}$ & $\begin{array}{l}\text { Sistem akan menampilkan } \\
\text { daftar pembayaran. }\end{array}$ & Valid \\
\hline 30 & $\begin{array}{l}\text { Owner mengklik menu } \\
\text { pemesanan. }\end{array}$ & $\begin{array}{l}\text { Sistem akan menampilkan } \\
\text { daftar pemesanan. }\end{array}$ & Valid \\
\hline 31 & $\begin{array}{l}\text { Owner mengklik menu } \\
\text { pembayaran. }\end{array}$ & $\begin{array}{l}\text { Sistem akan menampilkan } \\
\text { daftar pembayaran. }\end{array}$ & Valid \\
\hline 32 & $\begin{array}{l}\text { Owner mengklik menu } \\
\text { laporan. }\end{array}$ & $\begin{array}{l}\text { Sistem akan menampilkan } \\
\text { halaman laporan. }\end{array}$ & Valid \\
\hline 33 & $\begin{array}{l}\text { Owner tidak memilih pilihan } \\
\text { yang diberikan pada kolom } \\
\text { bulan. }\end{array}$ & $\begin{array}{l}\text { Sistem tidak akan menampilkan } \\
\text { tombol "print". }\end{array}$ & Valid \\
\hline 34 & $\begin{array}{l}\text { Owner memilih salah satu } \\
\text { pilihan bulan dan tahun. }\end{array}$ & $\begin{array}{l}\text { Sistem akan menampilkan } \\
\text { tombol "print". }\end{array}$ & Valid \\
\hline 35 & $\begin{array}{l}\text { Owner mengklik tombol } \\
\text { print. }\end{array}$ & $\begin{array}{l}\text { Sistem akan menampilkan } \\
\text { laporan pada bulan dan tahun } \\
\text { yang dipilih dan yang akan } \\
\text { diprint. }\end{array}$ & Valid \\
\hline 36 & $\begin{array}{l}\text { Semua aktor mengklik menu } \\
\text { log out. }\end{array}$ & $\begin{array}{l}\text { Sistem akan secara otomatis } \\
\text { keluar dan menampilkan } \\
\text { halaman utama web. }\end{array}$ & Valid \\
\hline
\end{tabular}




\section{KESIMPULAN DAN SARAN}

Berdasarkan hasil uraian dari bab-bab sebelumnya yang telah dibahas tentang sistem informasi jasa wedding organizer pada CV. Boganesia Jaya berbasis web, maka dapat ditarik kesimpulan yaitu mempermudah pelanggan dalam melakukan pemesanan wedding organizer melalui web serta mempermudah pihak CV. Boganesia Jaya dalam mengelolah data yang ada di perusahaan.

Setelah menyelesaikan pembuatan Aplikasi Sistem Informasi Jasa Wedding Organizer, diharapkan sistem yang baru ini mendapatkan masukan dan perbaikan untuk pengembangan sistem ke depannya. Adapun saran-saran yang diusulkan adalah sebagai berikut seetiap proses yang terjadi didalam perusahaan menggunakan penerapan sistem informasi yang sudah terkomputerisasi agar kinerja perusahaan dapat berjalan secara efisien dan juga efektif. Mengingat pentingnya peranan data yang disimpan, maka perlu dibuatkan file backup agar data yang sudah ada tidak rusak akibat adanya virus atau hal lainnya. Mengembangkan lagi perancangan aplikasi yang telah dibuat ini, seperti menambahkan fitur laporan pemesanan per bulan ataupun laporan pemesanan dan pembayaran, berserta detaildetail yang diperlukan di dalam sebuah laporan, selain itu istem aplikasi yang dirancang saat ini masih berbasis web diharapkan ke depannya aplikasi ini dapat juga diakses melalui mobile phone.

\section{DAFTAR PUSTAKA}

Anhar. (2010). PHP \& MySql Secara Otodidak. Jakarta: PT Trans Media.

Hamzah, D., \& Hadjib, M. (2013). Pemanfaatan Internet Sebagai Media Promosi Pemasaran Produk Lokal Oleh Kalangan Usaha di Kota Makassar. Kareba Jurnal Sistem Informasi, Vol.2 No.1 Januari -Maret 2013.

Kotler, P., \& Kevin, L. (2012). Manajemen Pemasaran. Edisi 12. Jakarta: Erlangga.

Kristanto, A. (2018). Perancangan Sistem Informasi Dan Aplikasinya (Edisi Revisi). Yogyakarta: Gava Media.
Mukhadis, A. (2013). Sosok Manusia Indonesia Unggul dan Berkarakter Dalam Bidang Teknologi Sebagai Tuntutan Hidup di Era Globalisasi. Jurnal Pendidikan Karakter, Tahun III, Nomor 2.

Taryana, S., \& Taryanarx. (2006). E Commerce Menggunakan PHP dan MYSQL. In: E-Commerce Menggunakan PHP dan MYSQL. Graha IImu. ISBN 978-979-756-182-6.

Soetam, R. (2011). Konsep Dasar Rekayasa Perangkat Lunak. Jakarta: Prestasi Pustaka.

Widhardin, I. (2010). Rupiah Meraih Dari Bisnis Wedding organizer. Jakarta: PPM.

Soetam, R. (2011). Konsep Dasar Rekayasa Perangkat Lunak. Jakarta: Prestasi Pustaka.

Mustaqbal, M. S., Firdaus, R. F., \& Rahmadi, H. (2015). Pengujian Aplikasi Menggunakan Black Box Testing Boundary Value Analysis. Jurnal Ilmiah Teknologi Informasi Terapan, Volume I, No 3, 10 Agustus 2015, ISSN: $2407-3911$. 